\title{
INTERNATIONAL OIL AND GAS DEVELOPMENTS: A CANADIAN PERSPECTIVE
}

\author{
M.E. BRUTON, C.J. CUMMINGS, J.D. TODESCO*
}

This paper identifies some of the factors prompting Canadian corporations to consider exploring for oil and gas in foreign countries. The basic contractual and regulatory regimes commonly employed in the major petroleum producing regions are outlined. Possible investment, financial, operational and legal issues arising out of international business are also canvassed.

\section{TABLE OF CONTENTS}

I. INTRODUCTION

II. EXPLORATION STRATEGY CONSIDERATIONS

A. ALBERTA DISCOVERY INDEX

B. WESTERN CANADA CRUDE OIL

C. DISTRIBUTION OF CRUDE OIL DISCOVERIES POOL SIZES, ALBERTA

D. WESTERN CANADA GAS

E. DISTRIBUTION OF GAS DISCOVERIES IN ALBERTA

F. INTERNATIONAL OVERVIEW

III. FORMS OF INTERNATIONAL PETROLEUM AGREEMENTS

A. HISTORICAL BACKGROUND

B. CONCESSION AGREEMENTS

C. PRODUCTION SHARING CONTRACTS

D. RISK SERVICE AGREEMENTS

E. COMMON PROVISIONS

IV. AN OVERVIEW OF SELECTED ISSUES 154

A. INVESTMENT ISSUES 155

B. FINANCIAL ISSUES 157

C. OPERATIONAL ISSUES 158

D. MARKETING 161

E. LEGAL ISSUES 162

F. GENERAL ISSUES 164

\section{INTRODUCTION}

Over the course of the past decade the involvement of Canadian oil and gas producers in international exploration has become increasingly significant. There are a variety of factors which have led major corporations to consider alternatives to the Western Sedimentary Basin and the Canadian Frontiers. This paper will seek to identify a number of those factors with particular emphasis on exploration strategies and economic considerations. The second part of the paper will summarize basic contractual and regulatory regimes prevailing in major producing regions throughout the world. The final section of the paper will deal with selected issues in negotiating and conducting business with foreign agencies and host nations.

* M.E. Bruton, Gulf Canada Resources Limited, C.J. Cummings, McCarthy Tétrault, and J.D. Todesco, Canadian Occidental Petroleum Lid. 


\section{EXPLORATION STRATEGY CONSIDERATIONS}

Western Canada oil and gas exploration is entering the mature phase of its life cycle. With respect to petroleum, the Western Canadian Basin is $85 \%$ mature - in that only $10-15 \%$ of the estimated ultimate oil potential remains to be discovered. In absolute terms, this represents something in the order of two to three billion barrels. The gas industry is slightly less mature as only $71 \%$ of ultimate gas reserves have been discovered. In a relative sense this underlines the greater potential of gas as compared to oil - a fact reflected by the increasing focus on gas exploration by Canadian producers over the last several years.

The maturity of Western Canada exploration has led a number of organizations to conclude that if current oil production rates are to be maintained, then conventional Western Canadian production must be supplemented with production from other sources. This need has been heightened with the recognition that it is unlikely that the Canadian Beaufort Sea will be developed before the next century. Similarly, the development of major discoveries in Eastern Canada including Hibernia and Terra Nova has been agonizingly slow. The inherent delays in developing the Canadian frontiers has provided producers with additional incentives to consider international exploration as a means of supplementing domestic production. 


\section{A. ALBERTA DISCOVERY INDEX}

One means of establishing exploration success within Alberta is the use of a discovery index which reflects the ratio of barrels of oil equivalent ("BOE") discovered in the year divided by the exploratory footage drilled in that year. Using this particular index, the most successful year in Alberta was in 1959 when just over 500 BOE were discovered per foot drilled. The exact number according to Energy Resources Conservation Board ("ERCB") records was 517 BOE of which 300 were oil and approximately 200 were gas. By 1987 the discovery index declined to $28 \mathrm{BOE}$ per foot; $18 \mathrm{BOE}$ of gas and $10 \mathrm{BOE}$ of oil. The discovery index is presently projected to continue to decline at approximately 10 percent per year, although this may be mitigated somewhat by the emphasis on gas exploration.

Cumulative exploration drilling footage has doubled in the past 10 years. During the period between 1969 and 1978 inclusive, the total footage of wells drilled in Western Canada was approximately 46,866,000 meters. By comparison, $91,306,000$ meters were drilled in Western Canada between 1979 and 1988.' However, in spite of this increased drilling activity, reserves of conventional oil have continued to decline in Western Canada.

\section{ALBERTA DISCOVERY INDEX -- BOE}

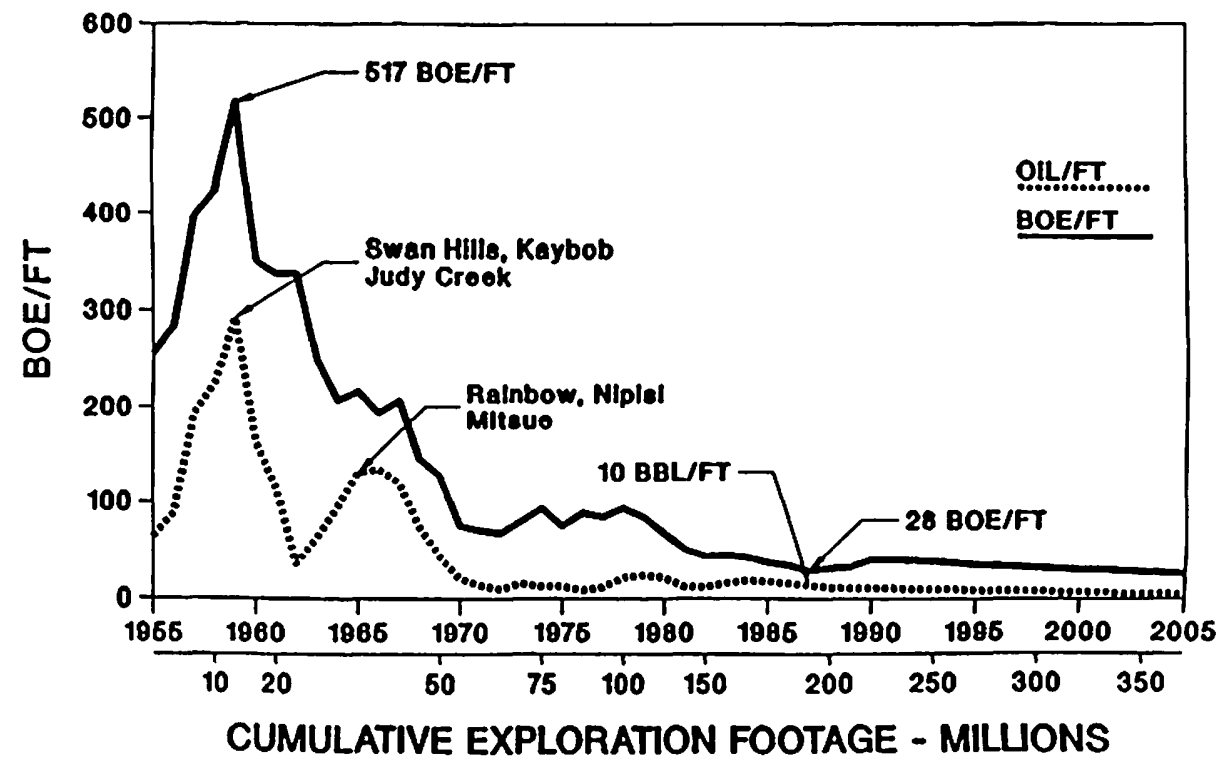

1. Canadian Petroleum Association Statistical Handbook, March, 1989, Section 1, Table 6. 


\section{B. WESTERN CANADA CRUDE OIL}

Approximately 17 billion barrels of oil have been discovered in Western Canada. As it is estimated that the ultimate potential of the Western Sedimentary Basin is in the order of 20 billion barrels, roughly $85 \%$ of the ultimate total reserves have been discovered.

Remaining reserves of conventional crude oil in Canada totalled 6.143 billion barrels at the end of 1988 . Of that total, 4.74 billion barrels represented reserves from conventional areas, principally in the four Western Provinces, plus 1.403 billion barrels of reserves from the Canadian Frontiers. ${ }^{2}$ At the current crude oil production rate of approximately $1,200,000$ barrels per day, there remains only 11 years of production from existing reserves (excluding the frontiers). It is also interesting to note that the quantity of remaining reserves in Canada peaked in 1968 at 10.495 billion barrels. Accordingly, within a span of 20 years, established reserves of conventional crude oil were reduced by over 50 percent. During the same 20 year period production consistently exceeded reserve additions - again reflecting the maturity of the basin.

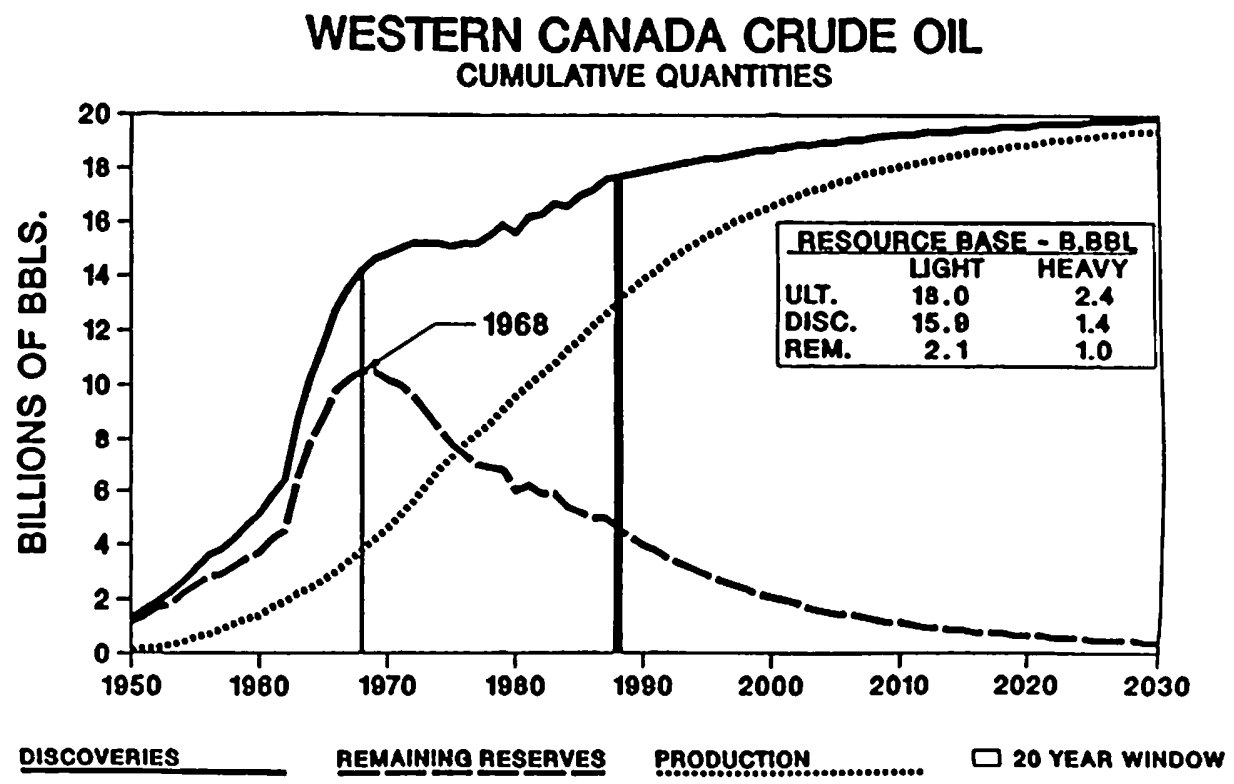

2. CPA Statistical Handbook, supra, Section 2, Table 1. 


\section{DISTRIBUTION OF CRUDE OIL DISCOVERIES - POOL SIZES ALBERTA, 1978-1987}

Another factor giving rise to consideration of exploration alternatives by Canadian producers is the relatively small size of most new oil discoveries. Given the overhead and infrastructure of large corporations it becomes uneconomic to operate pools below certain threshold sizes. This factor is also reflected in the current wave of "rationalizations" affecting the petroleum industry.

During the period 1978 to 1987,91 percent of pools discovered $(1,693)$ were less than 1 million barrels in size. Seven percent of the pools discovered (127) were between 1 and 5 million barrels. Only 2 percent were in excess of 5 million barrels in size. Accordingly, over the 10 year period only 29 new pools larger than 5 million barrels were discovered, an average of approximately 3 per year. However, those 29 pools represented approximately 33 percent of new reserves. Similarly, the 7 percent of pools in the 1 to 5 million barrel category contributed 32 percent of new reserve additions, while pools of less than 1 million barrels, while making up 91 percent in number, only contributed 35 percent of new reserves. In other words, the 9 percent of pools in the 1 million plus barrel categories represent almost two thirds of all additional reserves discovered. In total, only 156 pools greater than 1 million barrels in size were discovered between 1978 and 1987 - an average of only 15 per year were found during the period 1978-1987.

\section{DISTRIBUTION OF CRUDE OIL DISCOVERIES ALBERTA $1978-87$}

POOL SIZE

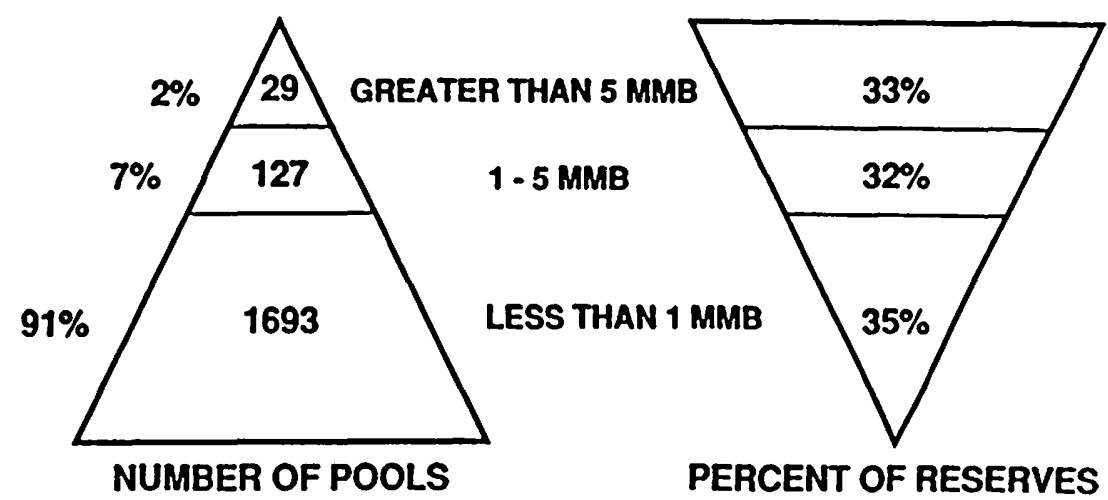

NUMBER OF POOLS 
The foregoing statistics underline the realities of future oil exploration in Western Canada. The larger fields have been identified and exploited and for the most part there remain smaller, less economic fields. While this may be disheartening and uneconomic for large organizations, it nonetheless presents opportunities for junior oil and gas companies which have eagerly exploited this niche. Faced with the need to achieve certain economies of scale, large producers are thus confronted with the prospect of simply depleting existing reserves, concentrating on new gas discoveries, or, as a third option, exploring for larger pools internationally.

In conjunction with pool size we must consider finding and development costs and success rate factors. The smaller the pool, the higher the success ratio must be in order to obtain equivalent finding and developing costs. Moreover, reduced average pool sizes afford less flexibility to operators to undertake wildcat exploration plays and run the risk of dry holes. It is apparent that smaller pool sizes require significantly higher successful drilling ratios to obtain satisfactory rates of return. Moreover, it must be recognized that even if an explorer is successful in finding oil, the economics quickly become very marginal if the well may only be produced at low rates.

In summary, approximately 85-90 percent of the ultimate light oil reserves in Western Canada have already been discovered; only 2-3 billion barrels remain to be found. Of the remaining pools in Western Canada more than 90 percent are projected to be less than 1 million barrels in size. Given these reduced pool sizes, satisfactory rates of return may only be achieved if historical average finding costs are maintained and coupled with high production rates. The absence of any of these critical factors may condemn the economic viability of certain prospects and, for certain organizations, oil exploration in Western Canada may no longer be viable option. 


\section{WESTERN CANADA GAS}

It is estimated that approximately 70 percent of natural gas reserves in Western Canada have been discovered. As noted previously, this is in contrast to more mature exploration for oil where the discovered reserves are closer to 85-90 percent of the ultimate reserve potential. Whereas remaining reserves of oil peaked in 1968, it was only in 1984 that reserves of natural gas reached their highest level. It is anticipated that reserves will continue to decline, reflecting the fact that industry is not likely to replace production. However, because of the larger quantity of undiscovered reserves, the decline in remaining gas reserves will not be nearly as precipitous as is the case with oil. Because of the larger resource base to draw upon, the immediate concern with respect to natural gas exploration is not so much the replacement of reserves but rather production rates and deliverability as the key factors affecting rates of return.

\section{WESTERN CANADA SALES GAS CUMULATIVE QUANTITIES}

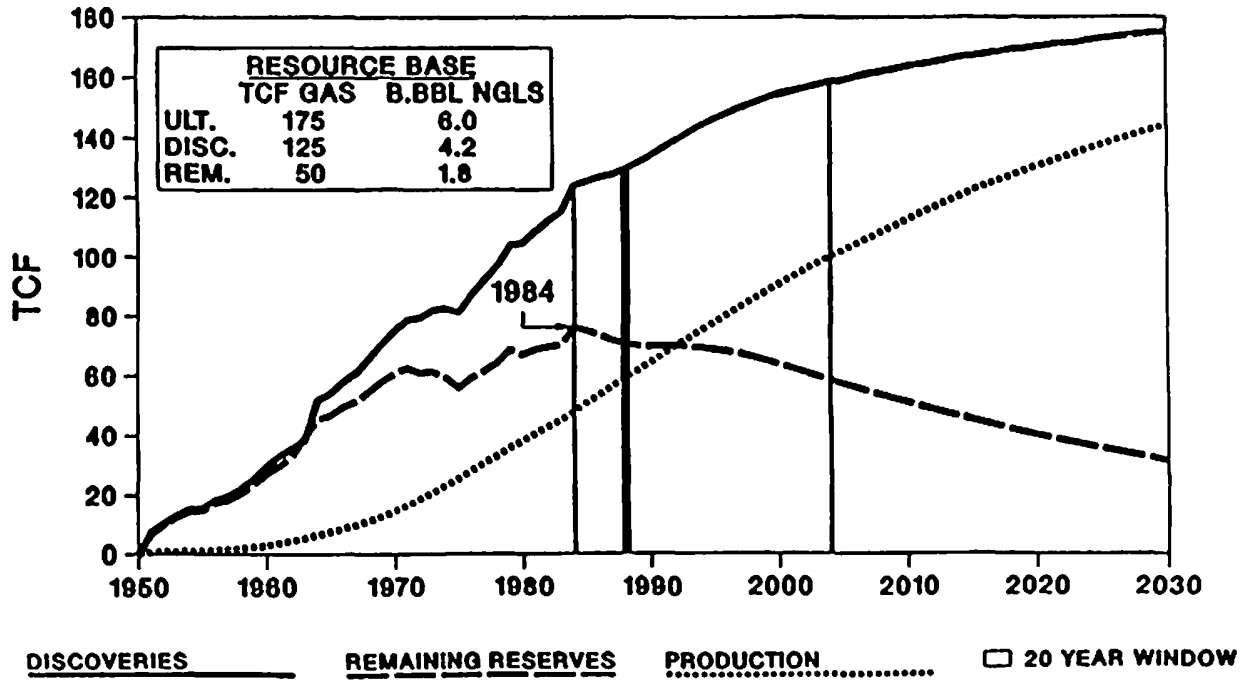




\section{E. DISTRIBUTION OF GAS DISCOVERIES IN ALBERTA - 1979 TO 1987}

The pool size of gas discoveries in Alberta during the period 1979 to 1987 parallels to a large extent the distribution of oil discoveries. ERCB data indicates that approximately 13 TCF of gas was discovered in Alberta in non-associated gas pools between 1979 and 1987. Ninety-eight percent of those pools contained less than 10 BCF of gas. Only 2 percent contained more than 10 BCF of gas. In absolute terms, only 36 of 8,391 pools contained more than $20 \mathrm{BCF}$ of gas. However, those 36 pools represented 16 percent of total additional reserves. The 98 percent of the pools less than $10 \mathrm{BCF}$ in size contributed 73 percent of additional reserves.

\section{DISTRIBUTION OF GAS DISCOVERIES ALBERTA 1979 - 1987}

POOL SIZE

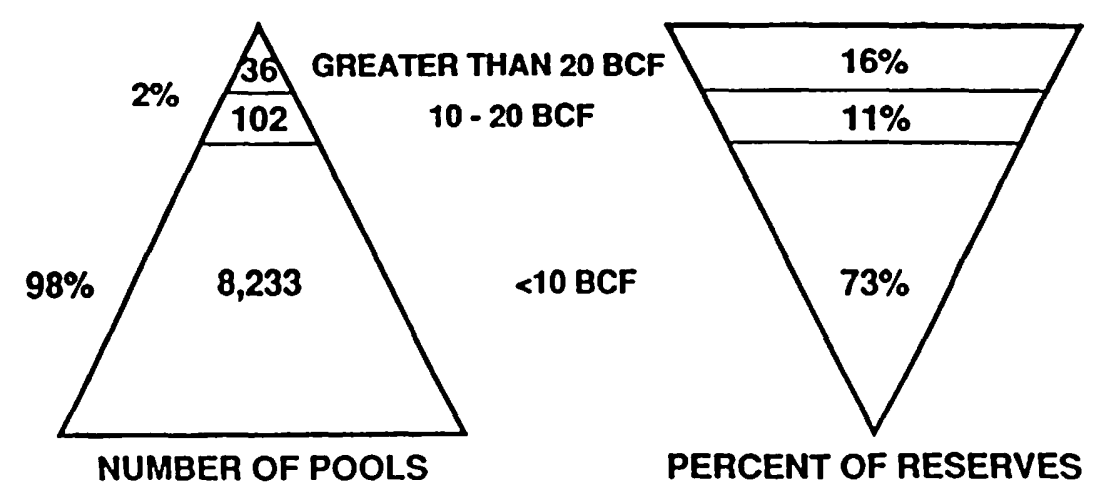

While 70 percent of ultimate gas reserves in Canada have been discovered, there remains considerably more potential than with respect to oil production. This in part accounts for the continuing shift towards natural gas exploration and production by Canadian producers. Moreover, the 70 percent figure becomes especially meaningful when compared to the percentages of undiscovered oil reserves in a number of different countries - where the percentage is often much lower, and accordingly affords more attractive opportunities, from an exploration standpoint. 
[VOL. XXIX, NO. 1

\section{F. INTERNATIONAL OVERVIEW}

It is estimated by the U.S. Geological Survey that ultimate oil potential worldwide is in the order of 1,770 billion barrels. In contrast to undiscovered reserves in the order of 2-3 billion barrels in Canada, the undiscovered amount internationally totals approximately 400 billion barrels or roughly 23 percent of ultimate reserves. Estimates of the percentage of oil discovered in certain countries make it apparent as to why these are considered to be especially attractive to Canadian explorers. For example, in the United Kingdom, it is estimated that the ultimate reserve potential is 27 billion barrels, yet total drilling footage is only in the order of 50 million feet compared to approximately 300 million feet in Canada. Discovered reserves approach 70 percent of estimate reserve potential - a figure which is comparable to the maturity of gas exploration in Canada. Similarly, in West Africa the footage drilled totals roughly 50 million feet and it is estimated that slightly less than 40 percent of ultimate oil reserves estimated at $\mathbf{1 8}$ billion barrels have been discovered. In Algeria and Egypt, with estimated total reserves of 36 billion barrels, only slightly more than 60 percent of ultimate total reserves have been discovered. Comparable figures are applicable in Indonesia where ultimate reserves approach 29 billion barrels. Australia and New Zealand represent even less mature exploration areas as less than 50 million feet have been drilled with discovered reserves approximating only $45 \%$ of total reserve potential.

What is perhaps most striking in considering exploration opportunities outside of Canada is the large resource base, particularly when compared to remaining undiscovered oil reserves in Canada. A second factor of note is the relative immaturity of exploration efforts in many of these countries. In what may perhaps be overly simplistic terms, it is this combination of vastly superior reserve potential, relatively immature exploration and a lack of opportunities in Canada which has caused a number of Canadian producers to view international exploration as a real opportunity for growth. However, it also entails operating in a new and different environment, bringing with it a host of problems governed by different legal and contractual regimes which will be considered in the next part of the paper. 


\section{FORMS OF INTERNATIONAL PETROLEUM AGREEMENTS}

The purpose of this portion of the paper will be to analyze the types of agreements currently utilized in the international petroleum industry by virtue of which an oil company obtains the right to explore for and produce petroleum substances either directly from a foreign government or through some agency thereof. Over the past 90 years the type of agreement utilized has changed dramatically. Therefore, in order to fully appreciate the rationale for the current contractual regimes, a brief synopsis of the evolutionary process is necessary.

\section{A. HISTORICAL BACKGROUND}

From 1901 to the late 1950 's, with relatively few exceptions, international oil and gas operations were dominated by eight major international oil companies, namely, the British Petroleum Company Limited (formerly the Anglo-Persian Oil Company), Gulf Oil Corporation, Texaco Incorporated, Standard Oil Company of California, The Royal Dutch Shell Group, Exxon Corporation, Mobil Corporation and Compagnie Francaise des Petroles. The original agreements could be characterized as "concession-type" arrangements, were usually quite simple in form and contained a number of standard provisions, including:

1. The duration of the concession was quite long, typically between 50 and 75 years, however some agreements were for a term as long as 99 years;

2. The area of the concession was usually very large, sometimes covering the entire national territory and relatively few, if any, of the earlier concession agreements contained any relinquishment requirements;

3. The agreements contained simple and small royalty obligations usually calculated on production tonnage with no reference to market value;

4. Exclusive rights were granted to the oil company with respect to all facets of petroleum activity, including the decision to bring new fields into production, the determination of production levels, the setting of prices, etc. State participation was not contemplated in any part of the petroleum operation;

5. There were relatively few or no time commitments with respect to the scheduling of the conduct of petroleum operations; and

6. Ownership of all petroleum substances produced from the concession area was vested in the oil company.

In addition, the early concession agreements did not provide for any possibility of a renegotiation of the terms and conditions should a change in circumstances warrant. To the contrary, a majority of the agreements contained provisions which specifically prevented the foreign government from exercising any form of sovereign power which would in any way affect the concession agreement.

Although occasionally criticized as being one-sided, with little benefit accruing to the foreign government, the circumstances surrounding most concession agreements were somewhat responsible for the nature of the negotiated terms. Concessions were usually granted by foreign governments with sometimes very little authority and often under the dominance of some foreign political power. The countries possessed little, if any, legal framework amenable to the issues involved in petroleum exploration. The oil companies, in an attempt to insulate themselves from the uncertainties associated with these factors, obtained a form of agreement which, to the greatest 
extent possible, allowed them to operate independent of any foreign government involvement.

With the end of World War II a second generation of concession agreement began to develop which provided for a more active role for the foreign government and a corresponding decrease in the responsibilities and rights of the oil companies. This evolution can be attributed to a number of factors, including an increased demand for oil, strong U.S. currency and the availability of unexplored areas, which in turn spurred increasing activity and resulted in increased competition among the expanding number of oil companies entering the international arena. As a result of the increase in demand for concession agreements, the foreign governments exercised new-found power with respect to the terms and conditions that it was willing to negotiate. As a result, new provisions began to appear in the concession agreements, which included:

1. The foreign government was given some representation on a type of operating committee;

2. The concession periods were limited to periods normally between 20 and 30 years;

3. Obligatory spending commitments and operating schedules were imposed; and

4. The royalty calculation referenced either a basket of world prices or a value more representative of the world market price.

This evolution ultimately led to the second form of agreement, the production sharing type contract. The significant aspects of this form of agreement were that the foreign government retained ownership of all petroleum and was responsible for the overall management of operations and, more importantly, a division of production replaced the former royalty/pricing sheme.

From the mid-1960's to the present, the type of agreements being utilized internationally evidenced the expanding technical and business expertise being obtained by foreign governments. In addition to concession agreements and production sharing contracts, a third form of contractual arrangement, the risk service agreement, has now begun to evolve which allows the foreign government to become directly involved in exploration and production activities and permits the oil company to simply reimburse itself for the provision of technical services, usually calculated at a premium, for the cost of exploration.

In addition, a form of service contract was previously quite popular but was limited in use to areas of risk-free operation. The oil company was usually paid a flat fee related to production for its services. Given the increase in international exploration over the past 20 years, this type of agreement has fallen into disuse.

The types of agreements to be discussed below are generally representative of the form of agreement which one could expect when negotiating the acquisition of exploration and production rights from a foreign government. However the precise terms and conditions of each contract need to be addressed individually as each may vary greatly depending on the current objectives of the foreign government, the proposed contract area, the risk involved, etc. 


\section{B. Concession Agreements}

As previously indicated, the concession type of agreement is the oldest and the most commonly used form of agreement, in use in more than 121 countries. Essentially, the major characteristic that distinguishes a Concession Agreement from any of the other forms is that ownership of all production is vested in the oil company subject to a royalty (payable in kind or in cash) and a tax on profits. As the foreign government has no right to take any share of the production, the royalty and tax regimes are usually higher than under any other form of agreement.

In certain circumstances, the foreign government retains the right to acquire a participating interest in the Concession Agreement. This usually involves some form of cost recovery payable out of the foreign government's share of production or, in some instances, an up-front cash payment by the foreign government for such costs and expenses.

\section{CONCESSION AGREEMENT}

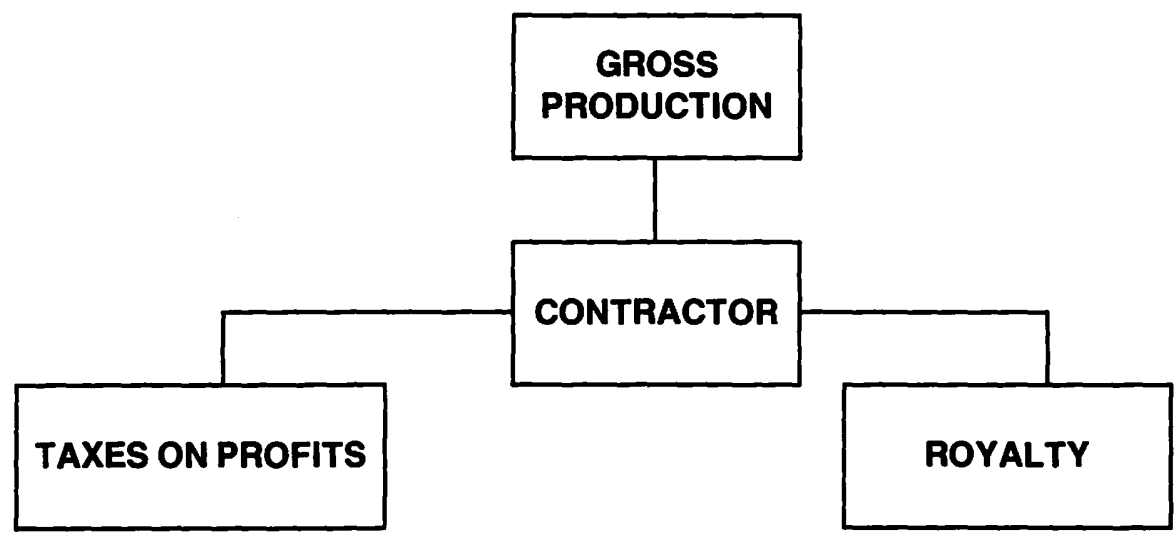

The form of concession agreement can be simple in that it can either be supplemented by an extensive legislative scheme or it may require further agreements to be entered into once certain elections are made by the oil company. For example, a concession may be divided into three phases:

1. In the initial exploration phase, the oil company is required to conduct certain exploration activities;

2. In the event that the oil company elects to proceed into the second phase which usually requires a drilling obligation, a further agreement may be required which outlines the ramifications of a commercial discovery; and

3. In the third phase, in the event of a commercial discovery, a joint operating agreement with the foreign government may be required if the foreign government has some form of participation right. Although initially simple in nature and conducive to the promotion of exploration activities, the Concession Agreement can become quite complicated in the event that elections are made to proceed to the drilling and/or development phases. 


\section{PRODUCTION SHARING CONTRACTS}

Although first used in Bolivia in the early 1950's, production sharing contracts are relatively new and are rapidly gaining in popularity. The current form of agreement which was first popularized in Indonesia in the early 1960's has since been put in use in a variety of countries.

The essential difference between a production sharing contract and a concession agreement is that the production sharing contract allocates production between the foreign government and the oil company. It is common in these circumstances that a portion of production is set aside so as to allow the oil company to recoup those costs and expenses incurred in the conduct of exploration and development activities.

The characterizations resulting from this allocation process are commonly referred to as "Cost Recovery Production" and "Profit Sharing Production".

1. Cost Recovery Production

A percentage of annual gross production is available to the oil company for reimbursement of recoverable costs on a monthly, quarterly or annual basis. This percentage is specifically designated in the production sharing contract and usually ranges from $30 \%$ to $40 \%$. The value of a given amount of cost recovery (i.e., the amount of reimbursement) credited to the oil company is usually defined as the available production multiplied by a price set by the terms of the production sharing contract, which generally approximates the current market price. The priority for recoverable costs is usually as follows:

(i) Operating costs, recovered in the time frame incurred; and

(ii) Amortized exploration and development expenditures. The amortization rate varies by contract.

All costs are usually ring-fenced by concession area. If there is insufficient cost recovery production in any given time frame, unrecovered costs are carried forward into the next frame for recovery.

If the value of the available cost recovery production exceeds recoverable costs in any given time frame, the production providing this excess value is defined as excess cost recovery. The treatment of the excess cost recovery varies by contract. Under some production sharing contracts, excess cost recovery is shared between the oil company and the foreign government in the same proportion as profit sharing production described below. Under other production sharing contracts, the entire amount of excess cost recovery is attributable to the foreign government.

2. Profit Sharing Production

Profit sharing production can be defined as gross production less "cost recovery production". Profit share splits are based on an incremental sliding scale in most agreements. As the level of production increases from the concession area, the share split changes between the oil company and the foreign government. 


\section{PRODUCTION SHARING CONTRACT}

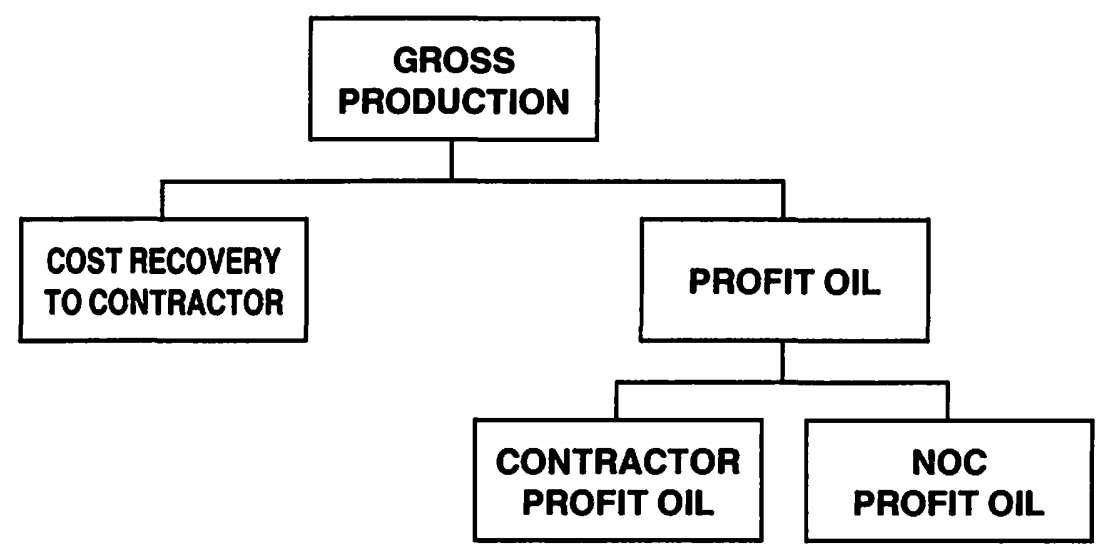

\section{RISK SERVICE AGREEMENT}

As evidenced by the name, risk service agreements are service contracts whereby the foreign government contracts for the technical, financial and commercial services of the oil company. If production is encountered, the oil company is reimbursed for the costs of its services. The basic distinctive feature of a risk service agreement is that the oil company is reimbursed in cash and not in crude oil for its costs of exploration and development, although there may be some provisions which permit the oil company to purchase crude oil by a credit of its cash payment based on some discounted pricing formula. Also the oil company usually receives interest on its investment and some form of compensation attributable to the risk associated with the venture.

In this type of agreement, the oil company is usually subject to taxation at the foreign country's general corporate rates.

\section{RISK SERVICE AGREEMENT}

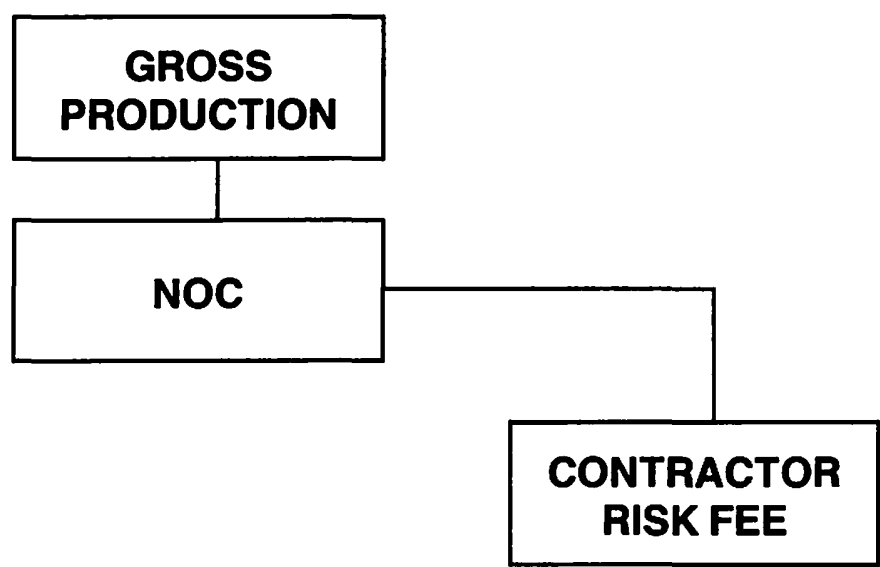




\section{E. COMMON PROVISIONS}

Subject to the proviso that each country may utilize a variety of forms and provisions, the three types of petroleum agreements generally have a number of common provisions, either included in the agreement or imposed by some additional agreement or legislation. These include:

1. Risk and Financing

It is common in all forms of petroleum agreements that all risk and expense are the responsibility of the oil company;

2. Work Programs

In each contract period for a contract area, a specific work obligation, expressed in dollars, kilometers of seismic or a number of exploration wells, serves as a basis for minimum work program obligations. Specific work programs must be submitted to and approved by the foreign government on an regular basis;

3. Timing of Performance

Very specific terms address the timing of the conduct of mandatory or minimum work obligations under the various contracts;

4. Operating Committee

A joint committee with representatives of both the foreign government and the oil company is established to provide for the overall supervision of operations. In certain instances where work programs and budgets are subject to government approval, the joint committee may only exercise an advisory role. In other instances it may constitute the final approving authority;

5. Surrender and Relinquishment

There is a normal requirement in almost all countries to relinquish a certain portion of the contract area within stated time limits. A survey of the laws of the different countries shows a considerable variation in relinquishment obligations. Generally, these obligations are stricter in proven oil countries than in countries with a lower potential for oil production.

The areas to be relinquished normally constitute between $50 \%$ and $75 \%$ of the original contract area. Relinquishment is typically made in two or three steps. $25 \%$ relinquishment in each stated phase or period is common.

Generally, areas found productive or potentially productive do not have to be relinquished. Surrenders are usually permitted at any time and are credited to the oil company's relinquishment obligation. The area to be surrendered or relinquished can be subject to certain restrictions as to configuration;

6. Supply of Information

An obligation to submit all information obtained during the conduct of exploratory work on a current basis is generally contained in the contract. This obligation usually comprises all relevant data (e.g., geological and structural maps, logs, samples, cores, etc.).

Although the government is supplied with such information and data, ownership usually rests with the oil company and the data is confidential for a certain period. Such confidentiality obligations may sometimes prevent the use of data for research and educational purposes. There are, on the other hand, agreements which give the foreign government ownership rights in such data, normally jointly with the oil company; 
7. Valuation of Petroleum

Valuation provisions are incorporated into most agreements for the purpose of;

(i) determining the value of cost recovery petroleum or the cost of the foreign government's back-in right payable out of production,

(ii) determining the compensation payable to the oil company in the event that the foreign government acquires the oil company's share of production, and

(iii) determining the value when petroleum is required to satisfy domestic demand. The valuation provisions were originally based on the actual realized price. However the current trend is to establish the price by reference to the weighted average of a specified group of international crude prices, allowing for quality and transportation adjustments. In other instances the foreign government will simply set the reference price;

8. Determination of Commerciality

The determination of a commercial discovery is usually still vested in the oil company; however in recent agreements, in the event that the oil company determines that the discovery is non-commercial, the foreign government could exercise a right to take over the well(s) for its own account;

9. Employment and Training

Most contracts contain provisions obliging the oil companies to provide training of nationals of the foreign country. Such obligations comprise both training of personnel for the oil company's own operations and training of personnel from the national oil company, the government and relevant government agencies;

Transfer of technology is required by some countries and this may necessitate a special agreement to assure patent protection and secrecy regarding technical processes. Care should be exercised in this area when dealing with foreign countries to which certain trade bans and embargoes apply;

10. Preference for Local Goods and Services

Generally contracts oblige the oil companies to purchase domestically produced goods and services, normally subject to the proviso that such goods and services are available on competitive terms;

11. Marketing

In earlier contracts the oil company was responsible for marketing all petroleum and, in turn, remitting the foreign government's share of proceeds. However, in recent agreements each party is granted a right to take its share of petroleum with a preferential right vested in the foreign government to purchase the oil company's share at some predetermined price;

12. Title to Assets

Under some contracts title to assets imported by the oil company for operations passes to the foreign country at the moment of importation. This does not include leased assets, such as contract drilling rigs. The oil company is given the right to the use of such assets until the expiration of the contract.

Where an oil company owns the production facilities, the contract will often provide that the ownership of these assets will revert to the foreign country upon expiry or termination of the contract. In case production is continuing at that time, such a provision may be useful. On the other hand, the duration 
of the contract may be longer than the production life of the field. In that case, reversion of assets to the state may be meaningless, because the production facilities will normally have little or no value if the field has been depleted. In fact, it may be necessary, for environmental or other reasons, to remove the facilities which may in some cases be extremely expensive. Therefore, in more recent agreements a specific provision provides the state with an option to either take possession of the assets or to request that they should be removed by the oil company;

13. Guarantees of Performance

A frequent provision in contracts is a requirement that the oil company must provide guarantees for its performance under the contract, including its fulfillment of work obligations. Such guarantees may also comprise any liability which the oil company may incur in respect of its activities, for example, for environmental damage and may be in the form of a bank guarantee or an unconditional guarantee from the parent company.

Performance guarantees are usually tied to the contractual obligations and divisible into periods, and allow for the reduction of the guarantee amount as certain expenditure thresholds are met;

14. Domestic Demand

Most contracts contain a requirement to meet the national demand for oil and gas out of local production;

15. Other Taxes \& Fees

It is generally true that the agreements between companies and governments for oil exploration and development specify income tax, royalty, occasionally a surface tax, and sometimes a stamp tax. They generally, however, specifically exempt the companies from payment of taxes other than those specified in the agreement or in the petroleum legislation. Export taxes are rarely levied, nor are import or export duties; and

16. Cash Bonuses

Bonuses may be of several types;

(i) Signature Bonus: payable upon signing of the agreement with the government,

(ii) Discovery Bonus: payable when a commercial discovery is made,

(iii) Production Bonus: payable as an agreed or stipulated amount upon the achievement of a stated level or levels of production.

A summary of a production sharing contract currently in use in the State of Aruba is attached, and should be of some assistance in conceptualizing what is set forth above.

\section{AN OVERVIEW OF SELECTED ISSUES}

This portion of the paper is directed to a consideration and review of selected issues commonly arising in the course of an international resource invesment. The issues set forth herein do not constitute an exhaustive list, but are merely intended to serve as a basis and foundation for indentification of further issues having regard to any specific country which is the subject of resource investment.

The increasing interest of Canadian oil and gas companies in, and commitment of significant resources to, foreign exploration and development investment opportunties has created a serious challenge for industry negotiators and their legal counsel. 
Typically, such professionals are neither equipped by education, experience nor inclination to the task of crafting the requisite business and legal framework within a foreign legal, investment and cultural environment. Moreover, foreign exploration and development opportunities are most often encountered within third world jurisdictions, where traditional accepted percepts of the "rule of law", "State conduct" and even "State authority" are virtually non-existent.

At the outset, it should be recognized that the representatives of a foreign jurisdiction commonly assert that their country has a model form of agreement governing resource investment from which no deviation may be made and in the result no amendment considered. Experience and investigation proves that these jurisdictions will in fact negotiate and approve collateral agreements or documentation such as memorandums of understanding or letters of clarification. The integrity of the model form and the public servant is thus preserved and an accommodation facilitated.

It may be observed that the cultural traditions of many foreign jurisdictions, together with associated business practices, create an investment environment which is both difficult to comprehend and appreciate. When this investment environment is combined with a judicial system founded on political considerations and continuing political influence, rather than the rule of law, as we understand that term, the apprehension of the investor is well founded. In short, the prospect for a spectacular return on investment is tempered by the corresponding high risk of that investment.

Finally, there is ample evidence to support the proposition that third world authorities will honor an agreement insofar as potential issues and matters are addressed therein, but any issue or matter not addressed will be resolved in favor of that authority absent any compelling economic motivation to the contrary. Indeed, it has been suggested there are few, if any, Canadian companies that have not paid a heavy price for their education in foreign investment endeavors. It is axiomatic that the negotiator and legal counsel will receive little gratitude for that corporate education when an investment fails.

For convenience of reference, selected prospective issues have been grouped to coincide with typical corporate areas of responsibility.

\section{A. INVESTMENT ISSUES}

\section{Form of Investment Agreement}

The selection or application of the type of agreement canvassed earlier in the paper in part governs the risk of the investment. For example, while the EPSA form of investment is most common to Libya (Risk Services Agreement), the length of time a company is financially exposed is somewhat greater than with other forms of investment. There is ample precedent to suggest that agreements other than the EPSA model may be negotiated which offer a reduction in risk and an accelerated return of investment capital. The production sharing concept of investment has merit where a large front end capital investment is required, as in a secondary or enhanced recovery project. Is there a choice in the form of investment agreement to be utilized, and if not, to what extent might the terms of the applicable agreement be amended, whether directly or indirectly? 
[VOL. XXIX, NO. 1

2. Investment and Production Ratios

In contemplation of both immediate development and production activities, has consideration been given to the opportunity to reduce investment risk by timing committed expenditures within the host country to anticipated production profiles and actual receipt of proceeds abroad?

3. Rights of Withdrawal

Have the negotiator and legal counsel considered methodologies of limiting financial commitments?

A company might reserve the right to withdraw from an agreement with respect to any area subject of a certain program (e.g. Appraisal Program), if the expenditure commitment for that year has been expended, with no further liability for that area. For example, if Area A constitutes land subject to a Development Program, Area B constitutes land subject to an Appraisal Program, and Area $C$ constitutes land subject to an Exploratory Program, the company would retain the flexibility to collapse the agreement as to Areas A, $B$ or $C$ if operations therein prove unsuccessful. In addition, or in the alternative, the company could negotiate the ability to transfer unexpended expenditure commitments for any calendar year between areas or to a new area on further negotiation with the host country.

Failure to contractually reserve a right of withdrawal could lead to disastrous consequences for the company, and, in the usual case, to further negotiations for a cash settlement. In the case of a development program, the company may negotiate the ability to withdraw in the event of technical difficulties such as inadequate water supply, excessive production decline rates, or inability to establish an economic secondary recovery production profile.

4. Commercial Production, Commercial Discovery

A clear definition of both events is both a delicate and crucial issue, as the decision to proceed to production is of vital importance to the host country, which often perceives its prospective revenue stream of more importance than the economic circumstances of the corporate investor. The company, desirous of recovering its capital expenditure within a reasonable time, together with a reasonable profit, is often held hostage to a host country adverse in economic interest, absent control by the company of the decision to proceed in its sole discretion. In addition, have all petroleum substances been specifically addressed and included?

6. Term of Agreement

How does the negotiator define the term of the agreement? Both the negotiator and legal counsel of one Calgary company negotiated a fixed term without regard to the concept of commercial production. The host country demanded the company continue to produce, even though the company lost approximately three dollars for every barrel produced when the market for the oil was thirteen dollars and production was contemplated to decline rapidly. Conversely, could the term expire prior to depletion of economic reserves?

7. Insurance

Have the corporate negotiator and legal counsel considered whether the company might qualify for insurance covering their investment in a high risk country, as made available through the Export Development Corporation of Canada? 


\section{B. FINANCIAL ISSUES}

1. Guarantees and Letters of Credit

It is a common practice for the host country to request either financial guarantees or letters of credit, or both, to support the expenditure commitment in amounts equal or proportional to the total expenditure negotiated. The form of the instrument is invariably negotiable, but it will normally be issued by the parent or head company as the entity of substance, irrespective of the investment vehicle utilized. In the circumstance of a letter of credit, participation of a major financial institution will be required. Opinion differs as to whether the provision of a financial guarantee is to be preferred to the letter of credit.

The decision taken is of obvious importance, as it will govern the flexibility of the company in its response to the most dreaded of all circumstances - the capricious demand by a sovereign State on such a financial instrument. The negotiator and legal counsel must carefully anticipate their future position in such an event. Choice of law, jurisdiction, preference in banking systems, forum, and the reliability of each are issues that must be considered prior to the commencement of negotiations. Analysis would suggest the debate as to the preferable instrument is largely based on subjective considerations. Experience suggests that it is an easier task to negotiate letters of credit utilizing the expertise of American, Japanese or Swiss financial institutions where possible, together with their attendant banking practices, to achieve the objective of limiting legal and financial risks.

2. Foreign Exchange

It might generally be observed that the record of the negotiator and legal counsel in negotiating and drafting acceptable exchange provisions is dismal. The large sums involved in the initial investment and subsequent marketing of production are seriously impacted by currency exchange provisions, particularly in financial regimes of the third world. The integrity of an international investment is potentially compromised if the following issues have not been addressed:

- is the treatment of the investing company no less favorable than that granted to any other foreign business or person doing business in the host country?

- is the investing company free to make payments and maintain accounts in any currency wherever situated?

- is the investing company authorized to make payment abroad in various currencies without conversion to the currency of the host country for goods and services required in that host country and to defray abroad in any currency other expenses incurred in operations?

- is the company free to repatriate funds loaned or advanced from foreign sources and invested in operations?

- do funds credited against repatriable funds include both charges for services performed by the corporate investor outside the host country and charges for material, equipment and supplies purchased outside the host country?

- is there a right to freely transfer abroad all profits without deduction or restrictions?

- is there a right to freely sell and purchase the currency of the host country as required for disbursements within that country, or in respect of repatriation and transfer, and at what rates? 
- is there a right to maintain accounts outside the host country and to retain or freely dispose of proceeds of export sales, without any attendant obligation to transfer funds or assets acquired outside the host country back to that host country? and

- what is the position of a sub-contractor in respect of the foregoing, having regard to projected costs associated with drilling etc.?

3. Customs, Taxes and Royalties

The majority of host countries are reluctant, and perhaps properly so, to entrench a fixed rate of tax or royalty in any agreement negotiated, as any future prospect of rising prices curtails participation in windfall profits. Nevertheless, it is urged that the negotiator and legal counsel consider the following issues:

- is it appropriate to impose a ceiling of taxes and royalties?

- in the case of a Risk Service Contract, it may be prudent to allocate to the host country responsibility for all such royalties and taxes (including those imposed on production, transportation or export), together with the obligation to provide a receipt for the same to the corporate investor as required for purposes of Canadian tax authorities; and

- ensure that contractors and sub-contractors are accorded similar treatment to maintain the integrity of the return of investment, as the investor will traditionally absorb such costs.

Customs duties present a significant opportunity for a host country to increase its revenue at the expense of the corporate investor. Depending on the nature of the agreement utilized, it must be established whether such duties are applicable to contractors and sub-contractors together with the corporate investor. If applicable, how are these charges treated in calculating deductions or profit oil etc.? Moreover, to what extent do any exemptions cover all aspects of the operations contemplated?

4. Proceeds of Production

Surprisingly, a recurring issue arises in respect of proceeds realized by the corporate investor from the dispostion of the host country. As previously indicated, the host country often demands that any such proceeds realized be repatriated to the host country. This is often a perplexing requirement, and one which is difficult to comprehend. Nevertheless, this requirement constitutes an issue which has resulted in acrimonious relations with the host country. It is often expensive and difficult to affect transfers of large sums of money expeditiously and efficiently, particularly when State banking systems are involved. It is suggested that any agreement negotiated specifically incorporate the right to retain the proceeds of production abroad. Bills of lading and documentation of the market transactions serve as ample evidence of the transaction for financial reporting requirements of the host country.

\section{OPERATIONAL ISSUES}

Host jurisdictions prospectively subject to resource orientated investments commonly lack a comprehensive legislative framework governing the relationships between the investor and the State. This is particularly evident in the petroleum industry as distinct from other forms of resource based investments. Absent such a com- 
prehensive legislative framework, the negotiator and legal counsel must contractually provide for the rights of the investor to facilitiate operations and to preserve the integrity of the investment. Failure to identify and provide for such rights creates complex and costly issues for both the State and investor.

\section{State Assistance}

An investor will negotiate certain basic issues in contemplation of operational requirements based on the circumstance of the particular host country. Some common matters arising in negotiations and incorporated contractually as rights of the investor are as follows:

- the investor is afforded full and unrestricted access to all data relevant to the Contract Area;

- full assistance of the State is given in securing visas, work permits, desert passes, drivers licenses, security protection, rights of way and easements;

- customs clearance priority procedures and arrangements are established;

- assistance of the State in expediting corporate registration and that of other third parties;

- provision of military and other government consents required for utilization of corporate aircraft and communication facilities;

- there is a transfer of all rights to the exclusive use of all existing wells, well bores and petroleum operation facilities within the Contract Area; and

- the company is given the right to open offices and establish corporate representatives and in some cases to own or lease property.

\section{Approvals}

Given the importance of petroleum revenues, there is a growing trend by host countries to condition any potential investment on direct supervision and control of all petroleum activities by a State authority. Such control is usually effected through an approval process. For example, the State authority is often designated as "Manager of Operations", and the corporate investor as "Operator". The Manager must approve all budgets and work programs implemented by the investing company. From the investors perspective, various issues consequentially arise which must be considered in determining the methodology of operating within the approval regime. For example:

- the potential for failure to approve or disapprove must be mitigated. Is it possible to contractually provide that failure to render a decision within a specific calendar period be deemed approval?

- may the risk of capricious decisions be avoided through sole risk provision;

- when an approval has been obtained, may any aspect of petroleum operations be subsequently altered by the Manager of Operations?

- what is the required scope of the reporting process?

- is the approval process and applicable timing requirement dependent on the prior submission of technical data and programs, and if so, may such data be coordinated with internal reports in format and detail?

- is it necessary to provide production programs on a contingency basis in order to maintain production? and

- is it necessary to provide personnel, technical assistance, and services to the State authority on a contingency basis? If the authority may request such assistance, what is the basis for charges for such services? 


\section{Personnel}

Numerous issues arise in placing personnel within a host country, with significant potential liability to the company and such personnel if they are not addressed:

- are medical services readily available of an acceptable standard, or may a corporate doctor be posted to the host country? May that doctor be authorized to treat nationals, and if so is insurance in place for malpractice?

- are American or Israeli nationals prohibited, or if not, is their personal security at risk?

- what are the implications of religious affiliations of personnel in the specific host country? and

- do facilities exist for families of posted personnel, and if so are restrictions in place on housing, education, movement, conduct, or women? May spouses work in the host country? Exxon, for example, had not anticipated that female spouses would attempt to enter the work force in the Middle East.

4. Facilities, Equipment and Services

There is a growing and concerted effort by host countries to secure other direct and indirect benefits for the State through corporate investment. The investor is pressed in negotiations to commit to utilizing nationals in operations, State airlines for travel, State transport (including trucking and ocean carriage), and national contractors for operational requirements. In some cases these requirements are considered onerous for legitimate reasons and companies in part responded by utilizing staging bases in locations in proximity to the host country as the preferred center of operations. For example, Singapore, with a sophisticated business infrastructure, served as the major staging base for resource investment in South East Asia. Indonesia, in turn, legislated the requirement that corporate investors in the petroleum industry doing business within that country open their offices in that country and moreover that a government sponsored staging base within their borders be utilized for future operations. In consequence, negotiations have often focussed on or included the following issues:

- is there a right to bring in foreign personnel for all required positions and a right to furnish all required technical aid from abroad?

- is there a right to purchase, lease and import all material, equipment, machinery, and supplies for petroleum operations from abroad? In this respect, experience suggests that one should make specific reference to clothing, foodstuffs, housing and recreational supplies;

- is there a right to permit head office personnel from abroad the right to inspect operations at all reasonable times?

- is there a right to use petroleum produced in the course of petroleum operations?

- is there a right of ingress and egress from the Contract Area and associated facilities at all times? For example, difficulties may arise where certain portions of the Contract Areas are restricted for unknown security reasons or military exercises are conducted for two calendar months of each year;

- is there a right to retain control of all property (including leased property) brought into the host country and a corresponding right to export that property freely and without impediment? For example, many countries require 
that all property introduced into the host country becomes the property of the host country when no longer utilized in petroleum operations. Unfortunately, it may not be perceived that leased property would be included within such a legislative provision and an inordinate length of time could expire before the property could be removed. In the mean time, the lease payments would countinue to be payable during the interim period;

- is there an unqualified right to engage and to select contractors of the investor's choice? While many countries require that priority be given to national contractors, a contractual provision is invariably negotiated which mitigages that obligation. The corporate investor in the usual case will agree to such a requirement provided the national contractor has the ability to provide the same advantages of service in terms of quality, availability and quantity and can provide the requirements within a $5 \%$ margin of a foreign contractor;

- is there an unqualified right to hire nationals of the investor's chocie?

- what are the capabilities of and access to port facilities within the host country? The negotiator and legal counsel will often determine that port capabilities are extremely limited both in access and cargo handling equipment. In such circumstances the corporate investor will invariably incur significant demurrage charges. Who will ultimately bear responsibility for the costs associated with such charges? and

- is the investor precluded from utilizing the services, goods or equipment of subsidiary companies? While there may be no direct prohibition, the costs and expenses associated with such goods and services may not qualify as deductions or credits under the applicable financial regime.

\section{MARKETING}

The marketing of petroleum substances is one of the most complex and troublesome aspects considered by the negotiator and legal counsel in crafting an acceptable agreement governing the international investment. In many cases, the host country requires that a portion of production be dedicated to meet national requirements. The host country will invariably adopt the position that the price for such dedicated production should be fixed, and that payment therefor will be made in the national currency. The investor is in consequence requested to predicate his investment in part on the variables associated with the commodities market in the currency of the host country and the inflationary cost of operations. Moreover, the host country is often incapable or unwilling to make payment for such production in hard currency. Negotiations hinge on reconciling the position of the host country with corresponding concessions to the investor in issues of export opportunities, production quotas, or utilizations of national petroleum facilities. The following matters may, without exception, be viewed in this context:

1. Disposition of Production

- is there a right to export freely and market the investor's share of production?

- is there a right, in the circumstances of over-lifting and under-lifting, to a payment to the under-lifting party? Is the payment to be made in hard currency or equivalent production? How does one establish a process for evaluation?

- who bears responsibility for commission and brokerage charges in the marketing of production? 
- will the corporate investor be requested to purchase unrelated production from a State marketing agency and market the same?

- is there a right to segregation of crude oils and condensate or gas of different qualities and grades?

- when does title to production pass to the investor? and

- is there a stabilization provision for uneconomic fields?

2. Utilization of Facilities

Does the corporate investor require the irrevocable right to utilize pipeline facilities, storage facilities, port facilities and marketing facilities necessary to effect the disposition and export of its share of petroleum production? Should the right to usage of such facilities be on terms no less favorable than those granted third parties?

3. Natural Gas Production

Surprisingly, negotiators and legal counsel often ignore the possibility of a discovery and production of natural gas. The resource investor may find it extremely difficulty to negotiate commercial terms for natural gas, after his investment has been made and operations implemented. Generally, in these circumstances the only market for such natural gas will be limited to the host country, but in the European circumstance some common issues arise:

- is the contractual treatment of natural gas production comparable to the provisions for processing, transportation and sale of curde oil?

- do the same considerations apply to disposal of and export of natural gas?

- when does title to the natural gas pass? and

- does the investor have similar advantages and rights of access to facilities associated with natural gas?

4. Production Quotas

The single most important issue ignored by negotiators and their legal counsel is that of the production quota. If the host country is a member of OPEC, the resource investor must contractually provide for the right to participate in the production allocation granted the host country. From the investor's perspective, that country is driven by two contradictory objectives: the need to increase or maintain its petroleum reserves through foreign investment and the need to maintain its revenue stream. The country may have nationally owned and operated oilfields with shut-in production and other foreign resource investors exerting continual pressure demanding a greater share in the national production allocation. In consequence, it is mandatory that in such circumstances the resource investor contractually provide for access to and a share in that national allocation.

\section{E. LEGAL ISSUES}

The legal issues typically encountered by the negotiator and legal counsel in the course of negotiating an investment agreement are dependent on such varied factors as the nature of the legal system of the host country, the choice of law, the type of agreement governing the investment, the history and culture of the host country, the sophistication of the host country in petroleum resource investment and the dispute mechanism utilized. The following legal issues have proved unusual: 


\section{Proper Parties to Agreement}

The law of many emerging nations often provides that all petroleum within the country is a national treasure and the national ownership of such a resource is vested in either a national oil company or various State corporate subsidiaries thereof. One would assume that the negotiation and execution of an agreement with the national oil company would secure the propriety of a transaction in respect to a subsidiary State corporation. Unfortunately, by reason of internal organizational and power structures, jurisdictional disputes are common and a subsidiary State corporation may contest the validity of any agreement reached. That precise circumstance confronted one Calgary company with the result that a conclusive agreement had to be renegotiated with all parties asserting an interest in the subject Contract Area. It is suggested that an identification of lands and interested parties is absolutely required to ensure the cooperation of all State authorities in the conduct of future operations;

2. Potential Claimants to Lands

As a result of the tumultuous period of nationalization of foreign oil companies in respect of land holdings in foreign jurisdictions, many such companies maintain claims to compensation or, in the alternative, a continuing interest in the subject lands. In the course of negotiating an agreement with a State agency, we were advised that a U.S. based company had a potential interest in the land and further that such party would launch a legal action through U.S. Courts for any production obtained from the lands or proceeds thereof. Our analysis indicated that the U.S. company would likely prevail in such a legal suit. It is therefore suggested that all such lands of current interest be considered with a view to potential claimants and letters of disclaimer obtained as necessary;

3. Approval to Agreement

It will often be determined that any specific matter addressed within an agreement negotiated with a national oil company having an impact on any other State authority, must have the consent of that authority. For example, certain exemptions from corporate tax obtained by an Italian oil company from a national oil company were refuted by the Minister of Finance subsequent to commencement of development operations. It was later established that this resource company was both required and expected to have obtained the consent of all government departments affected by the terms of the agreement, notwithstanding the ostensible authority of the national oil company;

4. The Investment Vehicle

Legal counsel must determine, having regard to specific host countries, the appropriate investment vehicle to be utilized having regard to domestic and foreign tax laws applicable. Is there a tax treaty between the two countries? Is it prudent to expose the parent company to the vagaries of the State business and judicial authorities? What are the corporate registration and local requirements respecting foreign companies? What is the penalty for failing to comply with annual reporting requirements, which might include loss of the concession? and 
[VOL. XXIX, NO. 1

\section{F. GENERAL ISSUES}

- are there limitations of Embassy or Consular services and what procedures are established for emergency situations?

- are SEC considerations relevant? If the shares of the corporate resource investor are publicly traded in the U.S. it may be subject to certain restrictions attendant on U.S. foreign policy respecting the host country;

- what is the scope of liability the investor is willing to assume? In many host countries, it is common practice that an Operator will not assume liability for gross negligence or wilful misconduct. For example, by reason of cultural differences between foreign and national employees, misunderstandings are common and relations between such employees extremely difficult. We had the experience of operating in a remote jungle region utilizing nationals as employees on land drilling rigs. Young expatriates supervised operations and gave directions to older national employees who had little experience in drilling operations. Foreign objects were repeatedly dropped in the well bore by the foreign nationals until it was determined that it was the strongest form of insult in that culture to receive instruction from a man obviously younger in age and wisdom. The problem was rectified by having the most senior older expatriate give all directions to national employees. It was later determined that this incident had cost the company 600 hours in drilling time;

- are there insurance limitations with respect to the contracting process?

- is the investor the exclusive agent of the host country with the sole rights to the Contract Area, or is the Contract Area contractually encumbered with any third party for other purposes?

- what is the proposed form for any arbitration process? Many host countries now demand that the arbitration provisions of that country be utilized, although the site of the arbitration and the choice of law have traditionally remained opened to negotiation; and

- have any payments been made to a foreign official or "expeditor" which do not qualify as a "facilitating payment" under the U.S. Foreign Corrupt Practices Act?

The foregoing brief overview of selected issues demonstrates that the negotiation of a foreign investment agreement may often be a complex and difficult undertaking, complicated by language barriers, cultural differences and conflicting judicial systems. We trust that the overview of selected issues may be of some utility to the practitioner who has aspirations in particpating in foreign investment transactions. 


\section{SUMMARY OF PRODUCTION SHARING CONTRACT FOR PETROLEUM EXPLORATION LICENSES OFFSHORE ARUBA OFFERED BY THE GOVERNMENT OF ARUBA}

PARTIES:

TYPE OF CONTRACT:

TERM:

RELINQUISHMENT: Subject to Commercial Discoveries and subsequent exploration obligations CONTRACTOR shall:

1. By the end of the Initial Exploration Period, surrender at least twenty-five percent (25\%) of the original total Contract Area.

2. By the end of the fourth (4th) Contract Year, surrender an additional area equal to twenty-five percent $(25 \%)$ of the original total Contract Area.

3. By the end of the fifth (5th) Contract Year, surrender an additional area so that the area retained thereafter is not in excess of seventy-five (75) square kilometers or 25 percent of the original total Contract Area, whichever is less. 
MINIMUM

EXPLORATION

PROGRAM; WORK

PROGRAMS AND

EXPENDITURES:
Items 1, 2 and 3 above do not apply to any part of the Contract Area corresponding to the surface area of any field in which Petroleum has been discovered and is in the course of Development, nor to a Production Area.

After mandatory surrender under item 3 above, CONTRACTOR shall maintain a reasonable Exploration effort. In respect of any part of such remaining portion of the Contract Area, CONTRACTOR shall drill at least one (1) Exploratory Well for every two (2) consecutive years or such part of the Contract Area shall be considered automatically surrendered.

CONTRACTOR may make certain surrenders (up to all of the Contract Area) in advance and receive credit for future required surrenders.

CONTRACT makes certain stipulations as to the size and shape of area surrendered. The portion to be surrendered requires NOCA's express written approval.

1. CONTRACTOR shall commence Exploration Operations within six (6) months after the Effective Date.

2. During the Initial Exploration Period, CONTRACTOR shall carry out at least the following minimum Exploration program:

a. Complete any additional seismic survey and interpretive work necessary to identify at least one

(1) drilling site within twelve (12) months of the Effective Date.

b. Drill at least one (1) exploratory well, to be spudded within eighteen (18) months of the Effective Date.

3. During the first extension to the Exploration Period, drill at least one (1) exploratory well.

4. During the second extension to the Exploration Period, drill at least one (1) exploratory well.

5. Excess work in one period may be credited against minimum obligations for a subsequent period.

6. Bank guarantee required in form in Exhibit " $D$ ". Five Million United States Dollars (U.S. $\$ 5,000,000$ ) for Initial Exploration Period. For extensions to the Initial Exploration Period equal to budgeted amount for the drilling of the required exploratory well and its supporting activities. Amount reducible by amount of each identifiable item of work.

7. CONTRACTOR shall provide NOCA, for NOCA's approval, a Work Program and Budget within three (3) months of the Effective Date and at least three (3) months prior to the beginning of each Calendar Year or at other mutually agreed times. NOCA's approval shall not be unreasonably withheld. 
OTHER SIGNIFICANT OBLIGATIONS OF CONTRACTOR:

\section{ASSIGNMENT:}

LIFTINGS:

IMPORT DUTIES:

JOINT REVIEW COMMITTEE:

RECOVERY OF PETROLEUM COSTS AND DISPOSITION OF PRODUCTION:
1. Establish a subsidiary and representative office in Aruba and register same in Aruba.

2. Bear responsibility in accordance with applicable law for any loss or damage to third parties caused by $\mathrm{CON}$ TRACTOR or its employees' or subcontractors or their employees' wrongful or negligent acts or omissions and indemnify NOCA and the Government against all claims and liabilities in respect thereof.

3. Pay to the Government all corporate and other tax on income imposed on it by Aruban law, subject to Article 8 of the Petroleum Ordinance. These taxes, contrary to other applicable taxes, are not recoverable under the cost recovery provisions under Section VI of the Contract.

1. CONTRACTOR may sell, assign, transfer, convey or otherwise dispose of all its rights and interests to any Affiliated Company with the prior written consent of NOCA, which consent shall not be unreasonably withheld.

2. CONTRACTOR may sell, etc., any minority portion to parties other than Affiliated Companies with the prior written consent of NOCA, which consent shall not be unreasonably withheld.

3. CONTRACTOR may sell, etc., a majority portion to parties other than Affiliated Companies with the prior written consent of NOCA and the government.

CONTRACTOR has the right to freely lift, dispose of and export its share of Crude Oil and retain abroad the proceeds obtained therefrom.

If no applicable exemption, NOCA shall assume and discharge Aruban import duties on materials, equipment and supplies brought into Aruba exclusively for Petroleum Operations. NOCA assumes no other taxes.

Established within ninety (90) days after Effective Date to review and make recommendations (advisory only) to NOCA and CONTRACTOR, e.g., term of contracts with subcontractors and performance of subcontractor's work. NOCA and CONTRACTOR have equal representation.

CONTRACTOR must market all Crude Oil produced and saved from the Contract Area.

CONTRACTOR recovers all Petroleum Costs from sales, proceeds or other disposition of Crude Oil not used in Petroleum Operations, provided that, in any Calendar 
NATURAL GAS:

\section{VALUATION OF CRUDE OIL:}

ADMINISTRATION AND SERVICE FEES:
Year, total amount of Crude Oil so allocated may not exceed fifty percent $(50 \%)$ of the gross production of such Calendar Year. To the extent that any amounts of unrecovered Petroleum Costs cannot be reimbursed from such fifty percent $(50 \%)$ of gross production in any Calendar Year, such unrecovered amounts shall be carried forward for recovery in the next succeeding Calendar Year or Years until fully recovered. CONTRACTOR may freely export such Crude Oil. Price of Crude Oil for cost recovery purposes is Net Realized Price as determined according to the procedure defined in Section VII of all Crude Oil produced and sold from the Contract Area during the Calendar Year.

Section 6.3 provides a formula for determining CONTRACTOR's share of Crude Oil after allowable cost recovery. The formula contains the biddable factor " $S$ ". Section 6.4 calculates NOCA's share of Crude Oil.

Title to CONTRACTOR's portion of Crude Oil (including that for cost recovery) passes to CONTRACTOR at the Measurement Point.

Either Party may take and receive its respective portions in kind. Contract provides procedure for NOCA to do so.

May be flared if its utilization is not economical in the opinion of both Parties; however, flaring is allowed only to the extent that gas is not required to enable the maximum economic recovery of Petroleum by secondary recovery operations, including repressuring and recycling. Any production and utilization of natural gas to take place pursuant to an approved Work Program. If CONTRACTOR declines, NOCA may do so on its own account. Contract foresees its amendment to make gas production commercially feasible.

A Net Realized Price to be determined quarterly or a shorter period as determined by the Parties. Section 7.5 provides a procedure to establish price if the Parties fail to do so. If the Parties cannot agree on a Net Realized Price, then the difference is to be submitted to arbitration.

CONTRACTOR pays NOCA an administrative fee of Five Hundred Thousand United States Dollars (U.S. $\$ 500,000)$ thirty $(30)$ days after NOCA furnishes CONTRACTOR an authenticated copy of the Minister's approval of the Contract. Not recoverable as Petroleum Costs.

CONTRACTOR pays NOCA an annual service fee of One Hundred Thousand United States Doilars (U.S. \$100,000) on each anniversary of the Effective Date. Recoverable as Petroleum Costs. 
MEASUREMENT OF PETROLEUM:

PAYMENTS:

TITLE TO

ASSETS:

RECORDS AND

REPORTS:

ARBITRATION:

TRAINING OF

ARUBAN

PERSONNEL:

FORCE MAJEURE: No default by a Party where performance of any obligation is directly prevented or delayed by any event or combination of events which could not be foreseen and was beyond the control of each Party.

TERMINATION:

NOTICES:

LAW:

Contract establishes standards of measurement and consequences of mismeasurement.

All payments to NOCA shall be made in U.S. Dollars. All payments to CONTRACTOR shall be made in U.S. Dollars or, at NOCA's election, in other currencies acceptable to CONTRACTOR.

NOCA becomes owner of all assets acquired and owned by CONTRACTOR in connection with Petroleum Operations carried out by CONTRACTOR. CONTRACTOR has exclusive use of such assets so long as required for the conduct of Petroleum Operations. Others may use assets if CONTRACTOR does not need exclusive use. CONTRACTOR shall not dispose of assets of major value, except with prior consultation with NOCA.

CONTRACTOR to maintain accurate and current records, using NOCA forms where applicable. Petroleum Data is NOCA's property.

Disputes not resolved between the Parties shall be resolved by arbitration in accordance with the rules of the International Center for Settlement of Investment Disputes.

CONTRACTOR must have reasonable plans and programs for industrial training and education of Aruban personnel.

Only NOCA may terminate during the Initial Exploration Period. CONTRACTOR may terminate at the end of any Contract Year following the end of the Initial Exploration Period, paying NOCA the unexpended remainder of the bank guarantee.

NOCA may terminate for any one (1) of five (5) causes specified in Section 16.3.5. If ninety (90) days after notice CONTRACTOR has not remedied cause or if NOCA has not agreed to CONTRACTOR's proposals to remedy or remove same, then NOCA may terminate Contract forthwith.

Either party may terminate Contract by written notce if the other Party commits a major breach, provided that such breach is established by arbitration.

Deemed to have been given when properly acknowledged for receipt by the receiving Party.

Contract governed by and construed in accordance with the laws of Aruba. 
PROCESSING OF

PRODUCTS:

ACCOUNTING

PROCEDURE:
Contract addresses possible equity participation in a domestic refinery.

Incorporated as Annex " C".

Depreciation for tax purposes is determined by applicable tax laws and regulations of Aruba.

Severence payments to local employees in accordance with applicable laws of Aruba.

Legal expenses solely related to defending interests of CONTRACTOR only are not recoverable.

Use of equipment or facilities owned by the CONTRACTOR or any of its Affiliated Companies is permitted only with NOCA's prior written approval.

Section VII describes non-recoverable costs, e.g., interest or financing charge on investment; income or other taxes incurred outside Aruba; marketing and transportation costs beyond the point of export.

Contract Year Work Program Budget Statement to be provided to NOCA at specified intervals. 